\title{
Owners Ethnicity And Strategic Management Accounting
}

\author{
Antonius Singgih Setiawan ${ }^{1}$, Rahmawati $^{2}$, Djuminah $^{3}$, and Ari Kuncara Widagdo ${ }^{4}$ \\ Fakultas Bisnis Akuntansi ${ }^{1}$ \\ Universitas Katolik Musi Charitas, Palembang Indonesia \\ Fakultas Ekonomi Bisnis ${ }^{234}$ \\ Universitas Sebelas Maret, Surakarta Indonesia \\ Email: singgih@ukmc.ac.id
}

\begin{abstract}
This study aims to prove differences in the level of the role of accountant and the implementation of strategic management accounting based on ethnicity categories of hotel owners. The study is conducted with quantitative methods using primary data through a survey of hotel general managers/leaders in the Sumatra region. A total of 395 questionnaires are distributed to the hotel general managers/leaders. The number of questionnaires used in this study is 224. Mann-Whitney nonparametric tests for two independent samples analysis is used to test research hypotheses. The results of the study indicate that there are differences in the role of accountant and the implementation of strategic management accounting based on differences in ethnicity of the hotel owners.
\end{abstract}

Keywords: Owners ethnicity, the role of accountant, implementation of strategic management accounting.

\section{INTRODUCTION}

The hotel industry practices are generally carried out by three main players, namely affiliates, management, and hotel owners, however, hotel owners often have an important role in determining hotel strategies (Xiao et al., 2012). This is supported by Chen and Tan (2013) who explained that ownership plays a role in the control and power of the company it owns. The type of ownership can be characterized based on the comparison of power between owners and operators/management (Turner and Guilding, 2013). Owners power can have an impact on the extent to which hotel top management has the ability to implement managerial policies (Park and Kim, 2014). (Kadir, 2014) explains that the personality values of company owners can influence the orientation of the company's business strategy.

However, the ethnicity cultural values of hotel owners play a role in shaping the level of power possessed by a hotel owner in intervening in management. The impact of implementing the owner's ethnicity cultural values on the hotel industry is how high the owner's support is in the implementation of strategic management accounting carried out by hotel management. It should be noted, two fundamental perspectives of strategic 
anagement accounting, namely the orientation of strategic accounting techniques and the involvement of the role of accountants (Cadez and Guilding, 2008).

Thinking of the relationship between ethnicity cultural values and the implementation of strategic management accounting is based on a contingency perspective. (Islam and $\mathrm{Hu}, 2012$ ) state that contingency theory is an approach to the study of organizational behavior in explaining how contingent factors such as technology, culture, and the company's external environment affect the design and function of an organization. This statement supports (Waweru, 2010) which states that the contingency perspective is able to explain the design of an appropriate accounting system based on organizational structure, technology, strategy and corporate environment including cultural factors.

The problem that often occurs in the implementation of strategic management accounting is that hotel owner and managers do not always have high goal alignment (Turner and Guilding, 2013). Implementation of strategic management accounting is an impact on the choice of competitive strategies (Turner et al., 2017) which will ultimately be related to relatively high-cost expenditures. For this reason, owners and managers often have different perspectives. Management will tend to spend maximally the owner's capital, on the contrary, the owner demands to save capital to benefit the owner (Turner and Guilding, 2010).

Therefore, the study of the characteristics of the ethnicity cultural values of the owners is interesting, especially related to the implementation of strategic management accounting in the hotel industry. This is based on several reasons, namely that currently the financial function of the hotel industry is becoming increasingly involved in strategic management accounting (Collier and Gregory, 1995). (Koning, 2007) explains that differences in ethnicity in the context of cultural values can have an impact on one's business behavior, including how hotel owners will support management in implementing strategic management accounting practices in their hotels. Culture as a characteristic of values, norms, and characteristics of a society, provides a structure of social interaction in a place (Brett, 2017), customary customs and culture of ethnicity will very likely influence business governance and lead to differences in commercial practices (Kania, 2010).

Based on the description above, a research opportunity arises to see whether differences in the characteristics of the ethnicity of hotel owners affect the implementation of the role of accountants and the use of strategic management accounting in the hotel industry. This is based on a phenomenon that shows that the differences in values of ethnicity culture held by an entrepreneur can influence the management of a business. This is because, cultural differences are important fundamental factors in conducting business (Kania, 2010). However, studies that explicitly see differences in the ethnicity of business owners as a factor in implementing strategic management accounting especially in the hotel industry are still rarely found. 


\section{THEORETICAL REVIEW}

Cultural values of ethnicity. Cultural values in management accounting research are based more on contingency perspectives. (Islam and Hu, 2012) state that the contingency theory can explain how culture can influence organizational design and function. Cultural values in a contingency perspective are often identified using (Hofstede's, 2011) five main dimensions of culture namely power distance, uncertainty avoidance, individuality collectivity, masculinity - femininity, long-term - short term orientation.

(Brett, 2017) explains that culture can be seen as a characteristic of values, norms, and characteristics of people in a country as well as political, economic and legal systems that provide the structure of social interaction in that place. The customs and culture of an ethnic group that has an impact on the socio-economic life of the community will very likely affect business governance in that place. The difference in ethnicity culture in one place will also very likely have an impact on leadership patterns in business organizations. The local culture of an ethnic group currently plays a very important role in the community. The habits that arise as a result of local culture will ultimately significantly affect one's leadership style (Semiarty and Fanany, 2017).

Culture also provides functional solutions to social interaction problems. People in different ethnic cultures will solve social interaction problems such as negotiations in ways that are also different. The problem of social interaction is often also related to the level of participatory approaches in business management both in the relationship between management and employees or between owners and management (Brett, 2017). (Zolkiewski and Feng, 2012) explained that the relationship model of business management portfolio in Chinese ethnic culture is a useful tool for management.

(Koning, 2007) has conducted a study of the characteristics of ethnicity in Indonesia in Pribumi ethnic groups and Chinese ethnic groups. The two ethnic groups are described as having different characteristics. Indonesian cultural values (Pribumi) are characterized as having a high value of collectivity, prioritizing seniority, oriented to stable and shortterm conditions (Mangundjaya, 2013). In contrast, ethnic Chinese are characterized as having an emphasis on innovative, creative and long-term orientation (Musianto, 2003). These two things have very strong contradictions. In addition, the Chinese ethnic private network is stronger than the private network of Pribumi. This personal network is not only the basis of access to capital and goods, however, but the use of this network is also seen as identic with trust and inherently different from the way of doing business between Pribumi ethnic and Chinese (Koning, 2007).

(Bachtiar and Amalia, 2012) found the conclusion that the Chinese entrepreneurial character was higher than the entrepreneurial character of the Minang and Malay ethnic groups. Obviously, the findings illustrate that more ethnic Chinese are entrepreneurs, while Malays and Minang ethnic prefer to become workers on the grounds that they can obtain definite income. Furthermore, (Bachtiar and Amalia, 2012) explained the reasons for Chinese ethnicity preferring to become entrepreneurs because of the ethnicity values inherited from their ancestors consistently and taught by parents in the family such as 
economical culture, hard work, should not be lazy, and should not give up. This is also one of the interesting phenomena which could be the reason why differences in Chinese and Pribumi ethnicity characteristics in business management need to be examined in the Sumatera region.

Strategic management accounting. The early 1980s were an important period in the evolution of both strategic management and strategic management accounting (Nixon and Burns, 2012). The evolution of strategic management accounting practices has an impact on the development of literature and research in the field of strategic management accounting. Some researchers have looked at the relationship between the dimensions of strategy selection, the use of management accounting to performance, some of these researchers are (Tavitiyaman et al., 2012); (Singla and George, 2013); (Teeratansirikool et al., 2013); (McManus, 2013); (Kalkan et al., 2014); (Mia and Winata, 2014); (Su et al., 2015); (Turner et al., 2017), performance measurement systems (Spekle and Verbeeten, 2014), management control system (Sakka et al., 2013), use of management accounting (Macinati and Pessina, 2014; Cleary, 2015; Uyar and Kuzey, 2016). (Bisbe and Malagueno, 2012) examine the strategic performance measurement system, and (McManus, 2013) examines customer accounting.

However, (Cadez and Guilding, 2008) state that there are two perspectives in strategic management accounting, namely oriented to strategic techniques and the involvement of accountants in the strategic decision-making process. Modern accountants in their role must base on the perspective of strategic management that is able to run a strategic accounting system as a tool of environmental analysis, selection of strategic alternatives, strategic implementation planning, implementation of strategic plans and as a process of controlling strategic management (Brouthers and Roozen, 1999).

(Cadez and Guilding, 2008) have the idea that the role of management accounting has shifted from conventional functions to strategic functions. Management accounting not only serves to provide data and reports administratively, however, but management accounting is also currently very instrumental in providing analysis, consideration in making long-term decisions. (Oliver, 1991) states that there is a positive relationship between participation in strategic decision making and the use of strategic management accounting, therefore, it seems reasonable when greater participation can be seen as a good motive for accountants to add value in the strategic decision-making process. (Fowler, 1999) explains that the majority of management accountants have played a role in implementing the quality concept into the company's accounting area. Therefore, (Cadez and Guilding, 2008) see accountants or accounting teams as part of the interdepartmental team in many companies that have more strategic roles.

Related to the implementation of strategic management accounting, (Nixon and Burns, 2012) explain that the concept of strategic management accounting is defined as the provision and analysis of management accounting data about the business and its competitors to be used in developing and monitoring business strategies. (Cadez and Guilding, 2008;2012) formulated sixteen strategic management accounting techniques into 
five categories, namely costing, planning, controlling and performance measurement, strategic decision making, competitor accounting, and customer accounting. These categories strengthen to the extent that the company relates to competitors, customers and the achievement of competitive advantage (Nixon and Burns, 2012). (Cleary, 2015) explains that the use of sophisticated management accounting systems will have a positive impact on the company's business performance, and (Turner et al., 2017) explains that the use of strategic management accounting can affect customer performance and financial performance.

Differences inthe role of accountant based on the ethnicity of hotel owners. The first hypothesis is based on (Friedman and Lyne, 1997) which explain the increasing role of accountants as a result of business-oriented management accounting innovations. Characteristics of innovation are characteristic of prospector competitive strategy (Cinquini and Tenucci, 2010). Increasing the role of accountants in business activities is also a result of the company's need to be able to select strategic alternatives, strategic planning, implementation of strategic plans and strategic management control processes (Brouthers and Roozen, 1999). However, the characteristics of business owners are an important factor in implementing corporate strategy choices (Blackburn et al., 2013) including the utilization of the role of accountants. The level of the role of accountants in companies can also be influenced by participatory principles owned by business owners.

Pribumi ethnic cultural values that tend to prioritize seniority (Mangundjaya, 2013) will have a different impact in accommodating the role of accountants than Chinese ethnic who prioritize participatory principles of the roles and responsibilities of superiors and employees in managerial activities (Pontjoharyo, 2011). The principle of seniority as widely adopted by Pribumi entrepreneurs tends to have an impact on the dominance of the owner's power in the practice of business decision making. On the contrary, the participatory principle will prioritize the collective role in decision making. This explanation shows an indication of the value of the principles of different ethnic cultures, especially in Pribumi and Chinese ethnic groups. In the end, these two different characteristics make it possible to have a different impact on the implementation of the strategic role of accountants in the company. For this reason, the hypothesis that will be proven in this study are:

H1: There are differences in the level of the role of accountants based on the ethnicity category of hotel owners.

Differences of use of strategic management accounting based on the ethnicity of hotel owners. The second hypothesis is based on the explanation that companies operating in competitive environments are advised to adopt sophisticated management accounting techniques (Shank, 1989; Roslender, 1995). Furthermore, (Kober et al., 2007) explained that the strategies used by companies would be related to the use of certain management accounting instruments. This shows that the more complex the strategy is implemented, 
the more sophisticated management accounting instruments will be needed. However, the implementation of strategic management accounting related to long-term strategic orientation will be faced with the cost requirements that are not small when compared to the implementation of traditional management systems that are short-term oriented.

Short-term orientation will emphasize efficiency (Cinquini and Tenucci, 2010), while, orientation to innovative, creative and long-term values will be more receptive to new things that are seen as providing more benefits in business management. Characteristics of ethnicity values emphasis on innovative, creative and long-term values are more owned by Chinese ethnic groups (Musianto, 2003). Furthermore, Chinese entrepreneurs will manage the profits to invest, including developing businesses and buying equipment that can be used to develop businesses (Koning, 2007).This is different from the values of Pribumi ethnic principles which tend to prefer stable situations and conditions and have a more short-term time orientation (Mangundjaya, 2013). (Blackburn et al., 2013) explained that the characteristics of business owners can be attached to the strategies and business plans implemented.

Based on some of the findings and explanations above, it is clear that there are indications of relevant relationships between innovative principles and strategic requirements for the application of strategic management accounting. Conversely, when business owners prefer the principle of short-term orientation, they will strive to improve efficiency. For this reason, the hypothesis that will be proven in this study are:

H2: There are differences in the level of use of strategic management accounting based on the ethnicity category of hotel owners.

\section{METHODOLOGY}

Research location. This research was conducted in the hotel industry in the Sumatera island region which covers 10 provinces, namely Aceh, North Sumatra, Riau, Kepri, West Sumatra, Jambi, Bengkulu, South Sumatra, Bangka Belitung, and Lampung. Several things are the reasons for the selection of research locations in the island of Sumatera, first, the growth of the hotel industry in the island of Sumatra is relatively the highest among other regions in Indonesia except to Java (Table 1). Second, the level of hotel competition on the island of Sumatera is relatively dynamic based on the average occupancy of the hotel. This is shown in the data on the performance of hotel occupancy rates which are relatively evenly distributed in star-class hotels in each province, but with relatively low numbers (average $48.44 \%$ in 2011-2015). 
Table 1. Comparison of Growth in Number of Star Hotels in 4 Regions Period of $2012-2016$

\begin{tabular}{|c|c|c|c|c|c|c|}
\hline \multirow{2}{*}{ Region } & \multicolumn{5}{|c|}{ Year } & \multirow{2}{*}{$\begin{array}{c}\text { growth in } 5 \\
\text { years }\end{array}$} \\
\hline & 2012 & 2013 & 2014 & 2015 & 2016 & \\
\hline Sumatera & 364 & 401 & 440 & 471 & 505 & 141 \\
\hline Java & 714 & 797 & 897 & 1.001 & 1.073 & 359 \\
\hline Kalimantan & 112 & 122 & 134 & 143 & 158 & 46 \\
\hline Sulawesi & 105 & 109 & 136 & 149 & 169 & 64 \\
\hline
\end{tabular}

Source: (data processed from BPS, 2012 - 2016)

Population, sample, and data collection method. The research population is all-star hotels on the island of Sumatra. The frame research sample is starred hotel data in the Sumatra region which was issued by the 2016 BPS totaling 505-star hotels.

The sample design in the research is using purposive sampling technique. The sample criteria are (1) 1 to 5-star hotels, this is based on the consideration that hotels in the star category are obliged to carry out the standards set by the association of hotel and restaurant entrepreneurs, (2) sell hotel services through online booking sites.This will help in identifying information about the hotel such as the address and criteria for hotel evaluation because BPS often does not provide complete data about the hotel. In addition, hotels incorporated in marketing agents carried out by online booking sites are certain to have followed certain standards set by online booking site management, so that can add confidence to the level of quality of the hotel in accordance with the star class owned by the hotel, (3) the hotel has been operating for more than 1 year. This needs to be done to ensure that the hotel has undergone operations and accounting activities in one round of the accounting period so that it can provide information that is relevant to the problem under study, and (4) the hotel is still operating when the survey is conducted because it is possible that the name of the hotel has not been removed from the site but the hotel has stopped operating. This study uses primary data types.

Table 2. Questionnaire Distribution

\begin{tabular}{lc}
\hline Description & $\begin{array}{c}\text { Number of } \\
\text { questionnaires }\end{array}$ \\
\hline Number of a questionnaire distributed to the respondents & 395 \\
Number of respondents refusing to participate & $(168)$ \\
Number of questionnaires returned incomplete & $(3)$ \\
Number of questionnaires returned and analyzed & 224 \\
Response rate & $56.71 \%$ \\
\hline
\end{tabular}

Source: (questionnaire collection process, 2018) 
Data is collected using survey techniques by providing questionnaires as research instruments aimed at research respondents who in this case are general managers (company leaders) of hospitality companies on the island of Sumatra. Based on the search results, the hotel names and addresses were recorded as many as 395-star hotels. 110 other hotel hotels not found. It is possible that 110 hotels do not market their services through hotel booking sites.

Based on 395 hotels surveyed, 3 hotels were less than 1 year in operation, 2 hotels were not operating, 163 hotels refused to be surveyed for various reasons. 3 hotels willing to be surveyed, but provide incomplete data according to research needs. 224 hotels are willing to be surveyed and provide complete data according to their research needs. Based on 224 questionnaires (with a response rate of 56.71\%) this study was conducted. Table 2 illustrates the distribution of questionnaires.

Data analysis method. Analysis of independent sample t-test is carried out using SPSS software. Independent sample t-test is an average difference test from two independent samples. The assumption of normality must be fulfilled before the independent sample $\mathrm{t}$ test is carried out, ie the sample must be taken from a normally distributed population and the sample must be taken from a different or unrelated sample. Normality testing can be done with the Kolmogorov-Smirnov test (Das and Imon, 2016). If the assumption of the normal distribution of data is not met, then the test will be conducted using the second alternative, namely the nonparametric Mann-Whitney test.

The role of accountants is an active role of an accountant in their contribution to producing business strategic decisions. The measuring of accountants' participation uses 5 instruments used by (Cadez and Guilding, 2008) which is adapted from (Wooldrige and Floyd's, 1990). Respondents were asked to identify the participation of accountants related to five aspects of strategic managementthrough a 6-point scale (1 has no role at all, 6 has a full role), namely; (1) Identifying problems and proposing objectives. (2) Generating options. (3) Evaluating options. (4) Developing details about options. (5) Taking the necessary actions to put changes into place.

The implementation of strategic management accounting is a system involves the use of advanced management accounting techniques in company operation. The system is implemented using 11 instruments introduced by (Cinquini and Tenucci, 2010), adopted from (Cadez and Guilding, 2008); (Cravens and Guilding, 2001); and (Guilding and McManus, 2002). Respondents were asked to indicate their implementation of management accounting techniques through a 6-point scale, ( 1 for never and 6 for always). Here are 11 strategic management accounting techniques: (1) Activity-based costing/management. (2) Life cycle costing. (3) Quality costing. (4) Target costing. (5) Value chain costing. (6) Customer accounting. (7) Competitive position monitoring. (8) Competitor cost assessment. (9) Competitor performance appraisal. (10) Benchmarking. (11) Integrated performance measurement. 
Ethnicity is defined following the definition of (Koning, 2007) as a collective identity which can be the initial and important dimension of self-identification. The owner's ethnicity in this study was grouped into two categories, namely (1) Pribumi and (2) Chinese. The grouping of ethnicities in these two categories is based on (Koning's, 2007) argument that Chinese ethnic networks are stronger than the private networks of Pribumi ethnic groups. This personal network is not only the basis of access to capital and goods, however, but the use of this network is also seen as identic with trust and is inherently different from the way of doing business between Pribumi ethnic and Chinese.

\section{RESULT}

Descriptive statistics. Based on Table 3, data on the role of accountants in hotel management activities in the Sumatra island region are seen based on the theoretical range $5-30$ in the actual range $10-30$. The average role of accountants is 23.72 . Based on these data it can be concluded that the role of accountants in hotel management activities in the Sumatera island region can be classified at a fairly high level.

Based on Table 3, the theoretical range of implementation of strategic management accounting on $11-66$, whereas the actual ranges vary from $22-66$. The average implementation of strategic management accounting is at 51.49. It can be inferred from those values that the implementation of strategic management accounting by hotels in Sumatera is relatively high.

This study identifies the ethnicity of hotel owners in the Sumatera region. Table 3 shows that the majority of hotel owners operating in the Sumatera island region are ethnic Chinese as many as 123 people (54.9\%). Hotel owners who are Pribumi ethnic are as many as 101 people $(45.1 \%)$. This data shows that hotel business activities running in Indonesia, especially on the island of Sumatera, are mostly carried out by Chineseethnic. This data also reinforces the fact that Chinese ethnic entrepreneurs are more numerous than Pribumi entrepreneurs in Indonesia.

Table 3. Research Data

\begin{tabular}{lcccc}
\hline Variable & Number & $\mathbf{( \% )}$ & & \\
\hline Owner Ethnicity & & & & \\
a. Pribumi & 101 & 45.1 & & \\
b. Chinese & 123 & 54.9 & & \\
\cline { 2 - 5 } & $\begin{array}{c}\text { Theoretical } \\
\text { range }\end{array}$ & $\begin{array}{c}\text { Actual } \\
\text { range }\end{array}$ & Mean & SD \\
\cline { 2 - 5 } $\begin{array}{l}\text { Role of accountant } \\
\text { Implementation of strategic }\end{array}$ & $5-30$ & $10-30$ & 23.72 & 5.17 \\
management accounting & $11-66$ & $22-66$ & 51.49 & 10.12 \\
\hline
\end{tabular}

Source: (Primary data processed, 2018) 
Data Validity and Reliability. Table 4 shows the results of testing the validity of research data. Validity test is based on the value of corrected item-total correlation (value of $r$ statistics). Based on the number of samples 224, all indicators of role of accountant and implementation of strategic management accounting variables are declared valid. It is proved that all of the corrected item-total correlation (value of $r$ statistics) significant at 0.05 . Table 3 also shows the results of the reliability testing of research data. Data reliability is based on the Cronbach alpha value of each data of the research variables. The results of the Cronbach alpha test show that the role of accountant and implementation of strategic management accounting variables have Cronbach alpha above the required critical value (0.8). Therefore, it can be concluded that the data of variables show reliable results, so the data feasible to be used for the further research process.

Table 4. Data Validity and Reliability

\begin{tabular}{llc}
\hline \multicolumn{1}{c}{ Variable } & Validity & Cronbach Alpha \\
\hline Role of accountant & $0.899^{* *}$ & 0.969 \\
RofA1 & $0.926^{* *}$ & \\
RofA2 & $0.922^{* *}$ & \\
RofA3 & $0.928^{* *}$ & \\
RofA4 & $0.885^{* *}$ & \\
RofA5 & & \\
Implementation of strategic & & 0.963 \\
management accounting & & \\
ISAM1 & $0.760^{* *}$ & \\
ISAM2 & $0.784^{* *}$ & \\
ISAM3 & $0.827 * *$ & \\
ISAM4 & $0.816^{* *}$ & \\
ISAM5 & $0.875^{* *}$ & \\
ISAM6 & $0.773 * *$ & \\
ISAM7 & $0.890^{* *}$ & \\
ISAM8 & $0.817 * *$ & \\
ISAM9 & $0.869 * *$ & \\
ISAM10 & $0.854^{* *}$ & \\
ISAM11 & $0.824 * *$ & \\
\hline
\end{tabular}

** Corrected item-total correlation significant at 0.05

Source: (Primary data processed, 2018) 
Table 5. Mann-Whitney Test of Owners Ethnicity

\begin{tabular}{lcrrr}
\hline \multicolumn{1}{c}{ Variable } & $\begin{array}{c}\text { Normality Test } \\
\text { K-S Z (Asymp. Sig) }\end{array}$ & \multicolumn{2}{c}{ Mean Rank } & $\begin{array}{c}\text { Asymp. Sig (2- } \\
\text { tailed) }\end{array}$ \\
\cline { 3 - 4 } & & $\begin{array}{l}\text { Chiness } \\
(\mathrm{n}=123)\end{array}$ & $\begin{array}{c}\text { Pribumi } \\
(\mathrm{n}=101)\end{array}$ & \\
\hline $\begin{array}{l}\text { Role of accountant } \\
\text { Implementation of }\end{array}$ & $2.802\left(0.000^{* * *}\right)$ & 121.86 & 101.10 & $0.016^{* *}$ \\
$\begin{array}{l}\text { strategic management } \\
\text { accounting }\end{array}$ & $1.631\left(0.010^{* * *}\right)$ & 128.55 & 92.95 & $0.000^{* * *}$ \\
\hline \multicolumn{1}{c}{$* * *$ significant at 0.01} & $* *$ significant at 5\% & & & \\
\hline
\end{tabular}

$* * *$ significant at $0.01 * *$ significant at $5 \%$

Source: (Primary data processed, 2018)

Normality Assumption. Based on Table 5 can be seen that the results of the Kolmogorov-Smirnov $\mathrm{Z}$ normality test for each study variable data have the value of Asymp. Sig K-S Z $<0.05$. This means that each research variable data does not meet the assumption of a normal distribution. Therefore, to prove the differences in the role of accountant and implementation of strategic management accounting on the ethnicity categories of the owners, the Mann-Whitney nonparametric tests were conducted.

\section{DISCUSSION}

Hypothesis 1. Table 65 shows the mean rank value of the role of accountants in hotels owned by Chinese ethnic is greater than the mean rank value of the role of accountants owned by Pribumi. The mean rank value of the role of accountants in hotels owned by Chinese is at 121.86 while the mean rank value of the role of accountants in hotels owned by Pribumi people is at 101.10 with a significance value of 0.016 or at $5 \%$. This finding shows that hotels owned by Chinese entrepreneurs on average have a better level of accountant role than the level of accountant's role in hotels owned by Pribumi entrepreneurs. Based on these findings, the research hypothesis which states that there are differences in the level of the role of accountants based on ethnicity categories of hotel owners can be supported.

The characteristics of business owners are an important factor in implementing corporate strategy choices (Blackburn et al., 2013), including the utilization of the role of accountants. For this reason, this study looks at the characteristics of business owners based on the values of the principle of the ethnicity of hotel owners. In general, Chinese ethnic cultural values generally prioritize the principles of participatory roles and responsibilities of superiors and employees in managerial activities (Pontjoharyo, 2011). In contrast, Pribumi ethnic groups are described as groups that tend to prioritize seniority (Mangundjaya, 2013).

The empirical findings of this study confirm some of these explanations. The findings show that the role of accountants in hotels owned by Pribumi ethnicity is lower than that of Chinese-owned hotels. The value of Pribumi ethnic culture which prioritizes aspects of seniority will tend to hinder the creation of participation in the organization. 
Therefore, it is reasonable if the level of the role of accountants in hotels owned by Pribumi ethnicity is lower than in hotels owned by Chinese ethnic.On the contrary, the value of Chinese culture that promotes a reliable, trustworthy, creative and innovative nature can direct organizational members to have higher participation (Musianto, 2003). The research findings confirm that with a high level of accountant participation in taking away the company's strategic decisions is a hotel owned by Chinese ethnic who prioritize participatory cultural values.

Finally, the findings of this study further reinforce the indication that the principle of seniority as widely adopted by Pribumi entrepreneurs tends to have an impact on the creation of the dominance of a center of power in decision-making practice. On the contrary, the participatory principle that prioritizes the collective role in decision making involving every function in the company will be more effective in increasing the functional role including the role of accountants.

Hypothesis 2. Table 5 also shows differences in the average rating values for the use of strategic management accounting for hotels owned by Chinese ethnic and hotels owned by Pribumi. The average rating of the use of strategic management accounting in hotels owned by Chinese ethnic is at 128.55 , this is also greater than the average rating value of the use of strategic management accounting in hotels owned by Pribumi ethnic groups at 92.95 and at a difference in the significant value of 0,000 or $\alpha 1 \%$. This finding shows that hotels owned by Chinese ethnic entrepreneurs on average have a level of use of strategic management accounting that is better than the level of use of strategic management accounting in hotels owned by Pribumi entrepreneurs. Based on these findings, the research hypothesis which states that there are differences in the level of use of strategic management accounting based on ethnicity categories of hotel owners can be supported.

The hypothesis of the differences in the level of use of hotel management accounting based on ethnicity categories based on short-term orientation strategies will emphasize efficiency (Cinquini and Tenucci, 2010), while strategies oriented towards innovative, creative and long-term values will be more receptive to new things which are seen as providing more benefits in managing the business. Differences in characteristics were reflected between the two ethnic groups namely the Pribumi and Chinese ethnic groups.

In the characteristics of ethnic values, Chinese ethnic groups emphasize innovative and long-term values (Musianto, 2003), manage profits to be invested, including developing business and buying equipment that can be used to develop business (Koning, 2007). Meanwhile, Pribumi ethnic groups tend to be short-term oriented (Mangundjaya, 2013). The choice of short-term orientation will direct entrepreneurs to the choice of efficiency strategies (Cinquini and Tenucci, 2010). For this reason, business owners will try to limit investment spending. Conversely, companies operating in a competitive environment and long-term thinking will adopt sophisticated management accounting techniques (Shank, 1989; Roslender, 1995).

The research findings confirm some of these explanations. The results of the study showed that hotel companies owned by ethnic Pribumi entrepreneurs implemented 
strategic management accounting that was lower than those of Chinese-owned hotel companies. This supports the findings of (Mangundjaya, 2013) that the characteristics of Pribumi ethnic cultural values tend to prioritize short-term approaches and will emphasize efficiency (Cinquini and Tenucci, 2010).

On the contrary, the Chinese ethnic emphasizes the orientation of innovative, creative and long-term values (Musianto, 2003) will be more receptive to new things that are seen as providing more benefits in business management. Therefore, it would be reasonable if, hotels owned by Chinese ethnic had higher use of strategic management accounting than hotels owned by Pribumi entrepreneurs. Finally, these findings indicate that differences in ethnicity characteristics in emphasizing value orientation into a business can have a different impact on implementing the use of strategic management accounting.

\section{CONCLUSION}

This study concludes that there are differences in the role of accountants and the implementation of strategic management accounting based on the ethnicity category of hotel owners. The results of the study showed that hotels owned by Chinese ethnic encouraged more the role of accountants and the implementation of the use of higher strategic management accounting. In contrast, Pribumi hotel owners tend to limit the role of accountants to lower levels of participation and the implementation of low strategic management accounting.

The findings of this study indicate and confirm that there are differences in characteristics of the two ethnic groups related to the role of accountants and the implementation of the use of strategic management accounting. Therefore, the implications of this study indicate the opportunity to develop a management accounting research model to look at the characteristics of ethnicity related to the implementation of strategic management accounting in a company. The results of the study also show the positive values possessed by Chinese ethnic that can be practiced and run business activities.

However, this research certainly still has limitations that it hopes can be improved and refined in future research. The limitation of the results of this study is that it has not seen the impact of the relationship between the ethnicity of the owner, the role of accountants and the implementation of the use of strategic accounting for achieving corporate performance. For this reason, future research can consider looking at performance achievements as a result of the relationship.

\section{REFERENCES}

BadanPusatStatistik. (2016). Statistik hotel dan akomodasi lainnya di Indonesia 2016. Jakarta: Badan Pusat Statistik. 
BadanPusatStatistik. (2015). Statistik hotel dan akomodasi lainnya di Indonesia 2015. Jakarta: Badan Pusat Statistik.

BadanPusatStatistik. (2014). Statistik hotel dan akomodasi lainnya di Indonesia 2014. Jakarta: Badan Pusat Statistik.

BadanPusatStatistik. (2013). Statistik hotel dan akomodasi lainnya di Indonesia 2013. Jakarta: Badan Pusat Statistik.

BadanPusatStatistik. (2012). Statistik hotel dan akomodasi lainnya di Indonesia 2012. Jakarta: Badan Pusat Statistik.

Bachtiar, N. and Amalia, R. (2012). "Analisis faktor-faktor yang mempengaruhi motivasi berwirausaha di kota Pekanbaru”. Jurnal Kependudukan Indonesia. 7(1). pp. 93 144.

Bisbe, J and Malagueno, R. (2012). "Using strategic performance measurement systems for strategy formulation: Does it work in dynamic environments?" Management Accounting Research 23 (4): 296 - 311.

Blackburn, R. A. Hart, M. and Wainwright, T. (2013). "Small business performance: Business, strategy and owner-manager characteristics". Journal of Small Business and Enterprise Development 20 (1): 8 - 27.

Brett, J. M. (2017). "Culture and negotiation strategy". Journal of Business \& Industrial Marketing 32 (4): 587 - 590.

Brouthers, K. D. and Roozen, F. A. (1999). "It is time to start thinking about strategic accounting?" Long Range Planning 32 (3): 311 - 322.

Cadez, S. and Guilding, C. (2008). "An exploratory investigation of an integrated contingency model of strategy management accounting". Accounting Organizations and Society 33(7/8): $836-863$.

Cadez, S. and Guilding, C. (2012). "Strategy, strategic management accounting dan performance: A configurational analysis." Industrial Management \& Data Systems 112 (3): $484-501$.

Chen, Z. and Tan, K. H. (2013). "The impact of organization ownership structure on JIT implementation and production operations performance". International Journal of Operations \& Production Management 33 (9): 1202 - 1229.

Cinquini, L. and Tennuci, A. (2010). "Strategic management accounting and business strategy: Aloose coupling?" Journal of Accounting \& Organizational Change 6 (2): $228-259$.

Cleary, P. (2015). "An empirical investigation of the impact of management accounting on structural capital and business performance". Journal of Intellectual Capital 16 (3): $566-586$.

Collier, P. and Gregory, A. (1995). "Strategic management accounting." International Journal of Contemporary Hospitality Management 7 (1):16 - 21.

Cravens, K. S. and Guilding, C. (2001). "An empirical study of the application of strategic management accounting techniques". Advances in Management Accounting 10 (1): $95-124$. 
Das, K. Y. and Imon, A. H. M. R. (2016). "A brief review of tests for normality". American Journal of Theoretical and Applied Statistics 5 (1): 5 - 12.

Fowler, C. J. (1999). "The management accontant's role in quality management: A Queensland perspective". International Journal of Applied Quality Management 2 (1): $41-57$.

Friedman, A. L. and Lyne, S. R. (1997). "Activity-Based Techniques and the Death of the Beancounter". European Accounting Review 16 (1): 19 - 44.

Guilding, C. and McManus L. (2002). "The incidence, perceived merit and antecedents of customer accounting: An exploratory note". Accounting Organizations and Society $27(1 / 2): 45-59$.

Hofstede, G. (2011). "Dimensionalizing cultures: The hofstede model in context". Online Readings in Psychology dan Culture 2 (1). Article 8.

Islam, J. and $\mathrm{Hu}, \mathrm{H}$. (2012). "A review of literature on contingency theory in managerial accounting”. African Journal of Business Management 6 (15): 5159 - 5164.

Kadir, N. (2014). "The influences of the performance of the owner's business and personality-based Small and medium enterprises: A study on SME's in Sengkang regency". Journal of Business and Management 16 (4): 21 - 24.

Kalkan, A. Bozkurt, O. C. and Arman, M. (2014). "The Impacts of intellectual capital, innovation and organizational strategy on firm performance". Procedia - Social and Behavioral Science 150 (September): 700 - 707.

Kania, S. M. (2010). "The role of cultural differences in forming a business strategy". Journal of Intercultural Management 2 (2): pp. 16 - 25.

Kober, R. Ng, J. and Paul, B. J. (2007). "The interrelationship between management control mechanisms and strategy". Management Accounting Research 18 (4): 425 452.

Koning, J. (2007). "Chineseness and Chinese Indonesian business practices: A generational and discursive inquiry". East Asia 24 (2): 129 - 152.

Macinati, M. S. and Pessina, E. A. (2014). "Management accounting use and fianancial performane in public health-care organisations: Evidens from the Italian national health service". Health Policy 117 (1): 98 - 111.

Mangundjaya, W. L.H. (2013). "Is there cultural change in the national cultures of Indonesia". In: Yoshihisa Kashima, Emmiko S. Kashima and Ruth Beatson (Eds.). Steering the cultural dynamics. Selected papers from the 2010 Congress of the International Association for Cross-cultural Psychology. Melbourne: IACCP: 59 68.

McManus, L. (2013). "Customer accounting and marketing performance measures in the hotel industry: Evidence from Australia". International Journal of Hospitality Management 33 (1): 140 - 152.

Mia, L. and Winata, L. (2014). "Manufacturing strategy and organizational performance: The role of competition and MAS information". Journal of Accounting \& Organizational Change 10 (1): 83 - 115. 
Musianto, L. S. (2003). "Peran orang Tionghoa dalam perdagangan dan hidup perekonomian dalam masyarakat (Studi kepustakaan dan studi kasus tentang interaksi etnik Tionghoa dan pribumi di bidang perekonomian di Surabaya)". Jurnal Manajemen \& Kewirausahaan 5 (2): 193 - 206.

Nixon, B. and Burns, J. (2012). "The paradox of strategic management accounting". Management Accounting Research 23 (4): 229 - 244.

Oliver, L. (1991). “Accountants as business partners”. Management Accounting 72 (12): $40-42$.

Park, J. and Kim, H. J. (2014). "Environmental proactivity of hotel operations: Antecedents and the moderating effect of ownership type". International Journal of Hospitality Management 37 (1): 1 - 10.

Pontjoharyo, W. (2011). "The analysis of Chinese character-based on accounting and value implications for Chinese Indonesian business". Asia Pacific Journal of Accounting dan Finance 1 (2): 150 - 164.

Roslender, R. (1995). "Accounting for strategic positioning: Responding to the crisis in management accounting". British Journal of Management 6 (1): 45 - 57.

Sakka, O. Barki, H. and Cote, L. (2013). "Interactive and diagnostic uses of management control system in IS projects: Antecedents and their impact on performance". Information \& Management. 50(6). pp. 265 - 274.

Semiarty, R. and Fanany, R. (2017). "The effects of local culture on hospital administration in West Sumatra, Indonesia." Leadership in Health Services 30 (1): $59-67$.

Singla, C. and George, R. (2013). "Internationalization and performance: A Contextual analysis of Indian firms". Journal of Business Research 66 (12): 2500 - 2506.

Shank, J. K. (1989). "Strategic cost management: New wine or just new bottles". Journal of Management Accounting Research 1 (1): 47 - 65.

Spekle, R. F. and Verbeeten. F, H, M. (2014). "The use of performance measurement system in the public sector: Effects on performance". Management Accounting Research 25 (2): 131 - 146.

$\mathrm{Su}, \mathrm{S}$. Baird, K. and Schoch, H. (2015). "The moderating effect of organisational life cycle stages on the association between the interactive and diagnostic approches to using control with organisational performance". Management Accounting Research 26 (1): $40-53$.

Tavitiyaman, P. Zhang, H. Q. and Qu, H. (2012). "The effect of competitive strategies and organizational structure on hotel performance". International Journal Contemporary Hospitality Management 24 (1): 140 - 159.

Teeratansirikool, L. Siengthai, S. Badir, Y. and Charoenngam, C. (2013). "Competitive strategies and firms performance: The mediating role of performance measurement". International Journal of Productvity and Performance Management 62 (2): 168 184 . 
Turner, M.J. and Guilding, C. (2010). "Hotel management contracts and deficiencies in owner-operator capital expenditure goal congruency". Journal of Hospitality and Tourism Research 34 (4): 478 - 511

Turner, M.J. and Guilding, C. (2013). "Capital budgeting implications arising from locus of hotel owner/operator power". International Journal of Hospitality Management 35 (1): $261-273$.

Turner, M. J. Way, S. A. Hodari, D. and Witteman, W. (2017). "Hotel property performance: The role of strategic management accounting". International Journal of Hospitality Management 63 (1): 33 - 43.

Uyar, A. and Kuzey, C. (2016). "Does management accounting mediate the relationship between cost system design and performance?" Advances in Accounting, Incorporating Advances in International Accounting 35 (1): 170 - 176.

Waweru, N. M. (2010). "The origin and evolution of management accounting: A aeview of the theoretical framework". Problems dan Perspectives Management 8 (3): 165 182.

Wooldridge, B. and Floyd, S. W. (1990). "The strategy process, middle management involvement and organizational performance”. Strategic Management Journal 11: $231-241$.

Xiao, Q. O'Neill, J. W. and Mattila, A.S. (2012). "The role of hotel owners: The influence of corporate strategies on hotel performance". International Journal of Contemporary Hospitality Management 24 (1): 122 - 139.

Zolkiewski, J. M. and Feng, J. (2012). "Relationship portfolios and guanxi in Chinese business strategy". Journal of Business \& Industrial Marketing 27 (1):16 - 28. 